\title{
The Gut Microbiota and Inflammation: An Overview
}

\author{
Zahraa Al Bander ${ }^{1, *}$, Marloes Dekker Nitert ${ }^{2}\left(\mathbb{D}\right.$, Aya Mousa ${ }^{1,+}+$ and Negar Naderpoor $^{1, *,+(\mathbb{C})}$ \\ 1 Monash Centre for Health Research and Implementation, School of Public Health and Preventive Medicine, \\ Monash University, Melbourne 3168, Australia; aya.mousa@monash.edu \\ 2 School of Chemistry and Molecular Biosciences, The University of Queensland, Brisbane 4072, Australia; \\ m.dekker@uq.edu.au \\ * Correspondence: zalb5@student.monash.edu (Z.A.B.); negar.naderpoor@monash.edu (N.N.); \\ Tel.: +61-38-572-2896 (N.N.) \\ + These authors contributed equally to this work.
}

Received: 10 September 2020; Accepted: 15 October 2020; Published: 19 October 2020

check for updates

\begin{abstract}
The gut microbiota encompasses a diverse community of bacteria that carry out various functions influencing the overall health of the host. These comprise nutrient metabolism, immune system regulation and natural defence against infection. The presence of certain bacteria is associated with inflammatory molecules that may bring about inflammation in various body tissues. Inflammation underlies many chronic multisystem conditions including obesity, atherosclerosis, type 2 diabetes mellitus and inflammatory bowel disease. Inflammation may be triggered by structural components of the bacteria which can result in a cascade of inflammatory pathways involving interleukins and other cytokines. Similarly, by-products of metabolic processes in bacteria, including some short-chain fatty acids, can play a role in inhibiting inflammatory processes. In this review, we aimed to provide an overview of the relationship between the gut microbiota and inflammatory molecules and to highlight relevant knowledge gaps in this field. Based on the current literature, it appears that as the gut microbiota composition differs between individuals and is contingent on a variety of factors like diet and genetics, some individuals may possess bacteria associated with pro-inflammatory effects whilst others may harbour those with anti-inflammatory effects. Recent technological advancements have allowed for better methods of characterising the gut microbiota. Further research to continually improve our understanding of the inflammatory pathways that interact with bacteria may elucidate reasons behind varying presentations of the same disease and varied responses to the same treatment in different individuals. Furthermore, it can inform clinical practice as anti-inflammatory microbes can be employed in probiotic therapies or used to identify suitable prebiotic therapies.
\end{abstract}

Keywords: gut microbiota; microbiome; inflammation; cytokines

\section{Introduction}

The understanding of the symbiotic relationship between the human gut bacteria and the overall functioning of the body has significantly deepened and broadened, with acceleration in research output concerning this area. While initial research generally examined the microbiota composition and its relation to disease presentation, there has recently been a more prominent shift towards the understanding of the mechanisms by which variation of the microbiota can lead to disease manifestation [1]. Clarifying these mechanisms can inform the development of novel therapies and optimise clinical practice. Moreover, discerning the structure and function of the microbiota becomes increasingly important in the era of precision medicine as this allows for personalised treatment to improve clinical outcomes [2]. This review presents a brief introduction to the gut microbiota, influential factors on microbiota, analysis techniques of the microbiome and interpretation of results. 
These are followed by a review of the recent literature on the interplay between the gut microbiota, metabolic diseases and inflammation. We explore potential underlying pathophysiologies and the intermediate biomarkers associated with gut bacteria and inflammatory diseases. Finally, limitations of microbiome studies are discussed, with recommendations for future research directions.

\section{What Is the Gut Microbiota?}

The gut microbiota refers to the microorganisms inhabiting the human gastro-intestinal tract. This dynamic community predominately encompasses species from the prokaryotic domain (comprising bacteria and other unicellular microbes lacking specialised organelles) and, to a lesser extent, fungi, parasites and archaea. Viruses are also constituents of this environment. The genetic and functional profile of microbial species is termed the gut microbiome [3]. On a broader level, humans can be classified according to their enterotypes, which are distinctly similar gut microbial compositions that can be observed in certain populations [4]. In a single individual, the inhabiting gut microbial species collectively have been shown to contain 3.3 million genes which, when compared to the human genome's $\sim 23,000$ genes, demonstrates the sheer magnitude and potential effect of these species on human health [5]. Moreover, the human body contains almost as many bacterial cells as human cells [6].

Bacteria can be classified through phylogenetic nomenclature into various levels of groups termed taxonomic ranks, dependent on genetic similarity. Organisms that are within the same lower taxonomic rank groups have greater genetic sequence similarities, indicative of more recent evolutionary divergence [7]. The modern classification system is illustrated in Figure 1. Members of the same species are most similar.

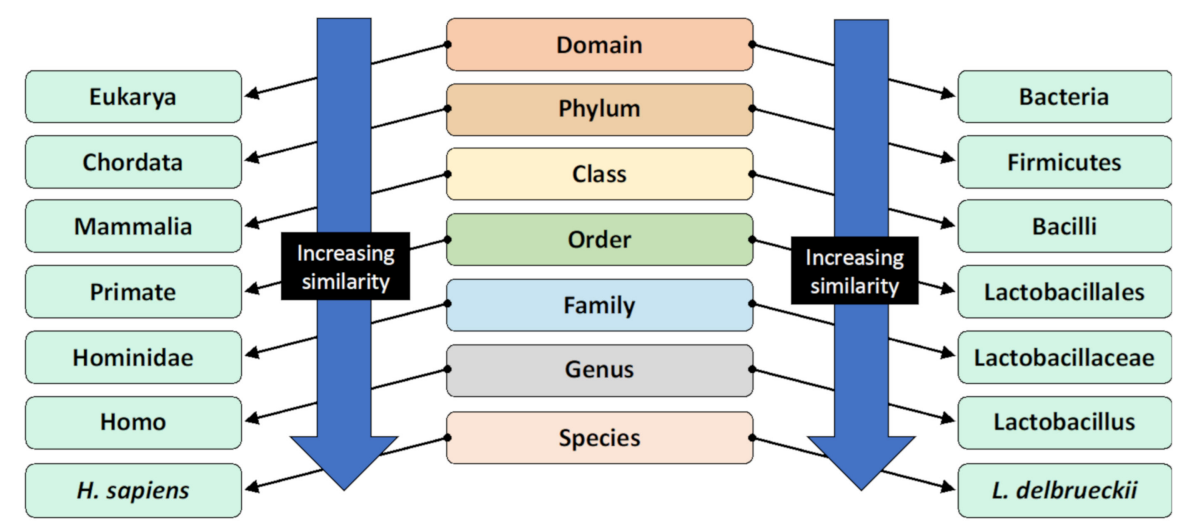

Figure 1. The taxonomic classification system and the classification of humans and Lactobacillus delbrueckii as an example [8]. Organisms are classified by this hierarchical system, where the most general and inclusive group is at the domain level. Organisms within the same species are most genetically similar.

\section{Methods for Studying the Gut Microbiota}

Researchers study the gut microbiota through various approaches, and it is the combination of these different methods that enables a comprehensive construction of knowledge revolving around gut microbiota and health. In human studies, the most established method of characterising the gut microbiome is stool sampling as it is readily available, non-invasive and densely populated by microbes representative of the luminal intestinal gut microbiota $[9,10]$.

Following collection, faecal samples are frozen and stored immediately, generally at $-80^{\circ} \mathrm{C}$ [11]. DNA is extracted from the faeces with two major steps. First, the sample is purified through the use of multiple reagents and centrifugation, allowing for the microbes to be stripped of other components of the faeces. The subsequent step involves lysing bacterial cells by incubating the samples with lysis buffer with agitation, such as vigorous shaking with or without beads, and carrying out further centrifugation [12]. Following this, the resulting DNA is amplified using approaches such as multiple 
displacement amplification [11]. A $16 \mathrm{~S}$ rRNA primer is selected and used for gene sequencing. The sequence data obtained undergo filtering to ensure the thresholds of quality are met. Subsequently, the sequence count is normalised prior to operational taxonomic units (OTU) analysis; the method by which related bacteria are grouped together. An OTU clustering algorithm is applied to identify bacterial genera and species [11]. The general protocol is summarised in Figure 2.

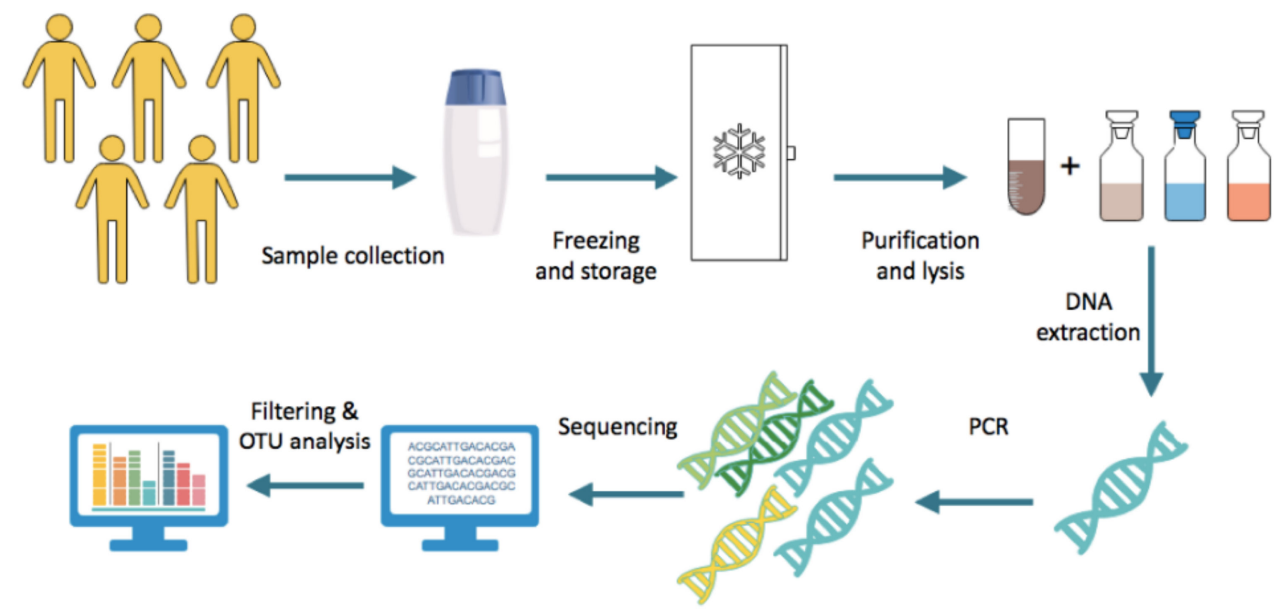

Figure 2. Steps generally undertaken in stool microbiome analysis.

Microbial diversity is assessed according to two parameters; alpha and beta diversity. Alpha diversity refers to the variation within a single sample, whilst beta diversity refers to that between samples [13]. These are generally determined in increasing order of relatedness, from phylum to genus, although some studies also employ species-level analysis [14]. Platforms facilitating these analyses include QIIME, a free software tool that evaluates 16S rRNA sequences [13]. However, using this lower rank classification could yield unreliable findings; most studies typically only assess one portion of the $16 \mathrm{~S}$ rRNA gene as opposed to examining the full-length of the gene [15]. Doing so compromises the reliability of species-level classification as a small portion of the gene can have a highly variable ability to detect species [15]. As reagents used in these steps may introduce contaminants, it is important to test for contamination with $16 \mathrm{~S}$ rRNA gene amplification, and computationally erase the contaminant species' sequences from the overall sequences obtained [11].

A more representative snapshot of the gut microbiota can be obtained through mucosal tissue sampling of the distal gastro-intestinal tract; however, this method comes with various limitations and is, therefore, less commonly used in research [16]. One such limitation is that compared to stool sampling, where human cell contamination is minimal, analysis of mucosal tissue biopsy samples must take into consideration the presence of human cells and genetic material as these may interfere with findings [10]. Other methods less routinely used include lavage and swab sampling, however, these have not been extensively evaluated in terms of protocol consistency and how representative the findings are of the gut microbial community [17].

Studies utilising animal models are key and frequent in this area of research as they enable a more comprehensive understanding of some aspects of the role of the gut microbiota in health. Confounders can be controlled more strongly in animal models, including rodents, fish and insects, to better understand experimental variables and their effects, and host-microbiota interactions $[10,18]$. This is particularly relevant in studies that seek to examine factors that affect the gut microbiota, or the effects of gut microbes on tissues or systems. Germ-free animal models have been utilised to assess microbiota-independent functioning in comparison to normal animal models [19]. Furthermore, gnotobiotic models are used in this field of study, where animals, typically rodents, are prepared with specific known strains or combinations of bacteria and are often genetically altered to determine the downstream effects of certain bacterial products or associated products [20-24]. Nevertheless, 
the results of studies on gnotobiotic models need to be interpreted with caution since the immune system of these animals is altered from early in development.

Cell culture systems are also important here as they can be used to further examine controlled interactions between gut microbes and other variables. These techniques may involve the cultivation of native-to-human-gut microbes, human tissue, or artificial tissue [10].

\section{Factors Associated with Microbiota Composition}

The gut microbiota in the gastro-intestinal (GI) tract develops during infancy. The process of microbial colonisation is contingent on a variety of host factors, described in more detail below. Additionally, different regions of the GI tract have different chemical environments that allow certain microbes to thrive more than others. Diversity and stability continually increase throughout early development, reaching a certain composition with age [25]. This composition may be modulated by various factors and life events, that may synergise to bring about greater diversity [1]. It is important to note that here, greater diversity is generally associated with better health outcomes, although there have been some reports of increased diversity in certain disease states [26,27]. Factors that influence the gut environment will in turn contribute to the characteristic gut microbial ecosystem thus giving rise to the inter-individual variation we observe.

\subsection{Mode of Delivery and Feeding}

Species that partake in the initial colonisation of the GI tract differ depending on the mode by which a neonate is born [28]. Both caesarean section and vaginal modes involve exposures to microbes, however, differences come about regarding the source of these microbes. In vaginal delivery births, the neonate is exposed to maternal vaginal bacteria and therefore, their initial microbiota compositions tend to reflect this region [29]. More specifically, these bacteria are part of the Lactobacillus, Prevotella and Sneathia genera. In contrast, those delivered by caesarean section are strongly influenced by their maternal skin flora and tend to have less diverse microbiotas [29,30]. As such, they have a higher portion of skin dwelling microbes including Staphylococcus, Corynebacterium and Propionibacterium species [29]. Additionally, intrapartum antibiotic use during casesarian section is shown to affect the neonatal gut microbiota [31]. Overall, a greater degree of similarity in gut microbiota has been observed between newborns delivered vaginally and their mothers, compared to babies delivered by C-section [32]. The role of the microbiota is critical in the development of the immune system, therefore differences in gut microbiota may explain why the latter category have a greater risk of developing infections or allergies [33,34].

In addition to the mode of delivery, the type of milk consumed early in life also affects the gut microbiota. Breast milk differs from formula milk as it contains its own bacteria and different bioactive compounds and nutrients. Specific species of bacteria may be better adapted for guts rich with their preferential nutrient, for example, dietary fibre, as they are able to extract their energy from these [35]. Because of this, Bifidobacterium species predominate in the microbiota of breastfed individuals, whereas Enterobacteriaceae species are more frequent in formula-fed infants [30]. Further, formula-fed babies have more diverse microbiota than their breastfed counterparts, suggesting that the benefits of breast-milk may be due to factors unrelated to the gut microbiota [32]. It is important to note that the gut microbial community undergoes many changes during the initial stage of development of a newborn, and that the effects of intrinsic and extrinsic factors may only lead to temporary and ephemeral structural changes [36].

\subsection{Diet}

Dietary behaviour can result in some strains dominating the gut more than others, and therefore specific downstream phenotypic characteristics in the host. Modifications to the diet will make different nutrients more readily available, consequently changing which strains dominate, contributing to the dynamic nature of the microbiota [37]. It has been revealed that individuals consuming more meat 
in their diets have significantly different gut microbiomes to those with plant dominant diets, due to certain bacteria flourishing in the abundance of protein [38,39]. For instance, Bacteroides species tend to dominate in the GI tract of those consuming animal protein, and Prevotella species are associated with plant-based diets [40]. Moreover, the effect of diet on gut microbiota can be seen in ethnography studies, where culture affects the general kinds of food consumed, and hence collective enterotypes [41]. This can be observed within Asian populations that have a high consumption of starch-rich foods like rice; the enterotypes of these populations are characterised by a notably high abundance of Bifidobacterium, a genus known to produce large quantities of starch-metabolising enzymes [4]. The Western diet, rich in saturated fats but low in unsaturated fats, has been studied extensively and found to be positively associated with anaerobic microorganisms and specific genera including Bacteroides and Bilophila [42]. In addition to the effects of specific macro and micronutrients in human diets on the gut microbiota, some animal studies have noted that additives commonly found in the Western diet have associations with altered microbiota composition and its inflammatory potential [43].

\subsection{Age, Sex and Body Mass Index}

Differences in the composition of microbiota have been noted with respect to age. In a cross-sectional study of 367 healthy participants in Japan, similar phyla were observed in the gut microbiome across age groups ranging from $0-104$ years, although in different proportions [44]. One trend reported was an association between age and abundance of Actinobacteria, where an increase in age was associated with a decrease in abundance. Microorganisms of the phylum Firmicutes became abundant in the microbiotas of individuals post-weaning stage, particularly past the age of 4 , whilst the inverse was seen with the Actinobacteria population. Bacteroidetes maintained a stable level of abundance across different age groups, although individuals above the age of 70 had higher levels of these microbes [44]. The patterns found in this study may be attributed to the various events that occur over the life course, including varied environmental exposures to microorganisms, occurrence of disease, hormonal changes and immune system functioning, thus complicating the influence of age on the gut microbiota $[44,45]$.

Although studied far less than other factors, sex differences have been noted to influence microbiota composition [46]. Differences become more apparent when investigating the microbes on a genus or species level. In an experimental study by Baars et al. [47], sex-related differences were found in how the gut microbiota interacts with the host. Using mice, they determined that compositional and transcriptional dissimilarities were apparent. In turn, these influenced the differences in lipid metabolism observed between male and female mice.

Haro et al. [48] found that Bacteroides caccae were more abundant in females than in males, whilst the inverse was observed for the species Bacterioides plebeius. Interestingly, these sex differences interrelate with body mass index (BMI). In the same study by Haro et al. [48], sex variation became more prominent when BMI increased. For instance, males exceeding a BMI of 33 had lower Firmicutes abundance than those of lower BMI, however, this trend was not observed in females. Rather, Firmicutes abundance remained high irrespective of BMI in female participants [48]. These observations are hypothesised to be due to hormonal differences, however, more research must be conducted to understand the exact mechanisms [49]. In general, an association with BMI and gut bacterial diversity has been reported, with a pattern demonstrating that an increase in BMI strongly correlates with decreased diversity [50]. Further, there is a reduced proportion of members of the phylum Bacteroidetes compared to Firmicutes in obesity, and upon weight loss, this ratio reverts to normal [51].

\subsection{Host Genotype}

Specific host genotypes are associated with differences in gut microbial diversity, as well as specific community structures [52]. As genes affect immune system functioning and susceptibility to disease, certain alleles are associated with certain compositions. For example, individuals with the rs651821 variant of the gene APOA5 are more likely to have members of the Lactobacillus, Sutterella and Methanobrevibacter genera in their microbiota, which subsequently correlates with a greater risk of 
metabolic disorders [52]. Specific variants of microbiome-associated genes have been shown to be associated with conditions including obesity, shizophrenia, type 2 diabetes, amyotrophic lateral sclerosis and inflammatory bowel disease, in a number of studies [53]. One such example is the SLIT3 gene; this gene appears to play a role in microbe product-induced inflammation, and in a genome-wide association study, variants of the gene were found associated with BMI, suggesting a likely relationship between the gene, its molecular product, the human microbiome and obesity [53].

One polymorphic aspect of human genetics associated with predisposition to autoimmune disorders is the human leukocyte antigen (HLA), which are cell-surface proteins that are encoded by a cluster of genes. The variation in HLA structure and underlying genetics has been shown to correlate with distinct changes in the gut microbiota [54]. For instance, the relationship between the variant HLA-B27 and the inflammatory condition ankylosing spondylitis has been well documented in the literature [55]. One study examining individuals with this particular genotype found that there is a distinct gut microbial profile associated with HLA-B27, suggesting that ankylosing spondylitis may be driven in part by a genetic predisposition to specific immunological processes, mediated by the gut microbiota [56].

It should also be noted that existing findings lend to the idea that the composition of the human gut microbiota is influenced mainly by non-genetic factors [57]. Nonetheless, this area of study is still in its infancy and further studies in larger cohorts are underway to better understand how the gut microbiota and human genome interrelate.

\subsection{Antibiotic Use}

When exposed to antibiotics, the host microbiota can undergo quick alterations in its structure, depending on the type and regularity of use. A common outcome is a state known as gut microbiota dysbiosis, whereby there is an imbalance within the microflora, consequently impairing its functioning [58]. Other factors, including diet, infection and existing disorders, may also cause dysbiosis. An individual with dysbiosis will face an increased risk of a plethora of morbidities, namely infection, as a healthy, balanced microbiota serves as a hindrance to potential pathogenic strains, competing for resources and preventing the growth of invading microbes [59]. Other outcomes associated with dysbiosis pertain to immune system and metabolic deregulation. Findings from a large international cross-sectional study of 74,946 individuals exemplify the effects of antibiotic-induced dysbiosis; it was found that the use of antibiotics within the first year of life in male subjects contributed to metabolic dysregulation and therefore an increase in BMI in later stages of childhood, but not in females [60].

\section{Role of the Gut Microbiota in Immunity and Inflammation}

Microbes possess a variety of functions that influence their ability to grow and colonise, whilst bringing about downstream effects for the host that may be beneficial or otherwise [61]. Humans are not capable of digesting some components of dietary fibre due to the lack of the required enzymes to break down and harness the energy of these carbohydrates [62]. Certain species of microbes produce specific enzymes that enable fermentation of nutrients into absorbable forms, including that of indigestible carbohydrates into short-chain fatty acids (SCFAs) [62,63]. These SCFAs may have anti-inflammatory and immunomodulatory effects [63]. SCFAs are only a small part of the bigger picture as, in addition to enzymes and other metabolites produced, components of the bacteria themselves, including lipopolysaccharides, cell capsule carbohydrates and other endotoxins, may also be released and result in secondary effects to the host. These effects include maintenance of gut epithelium (and thereby integrity of the gut wall), production of vitamins, and interactions with several key immune system signalling molecules and cells, activating and inhibiting specific responses [1]. In addition to nutrient metabolism, gut microorganisms affect aspects of pharmacokinetics as they carry out drug metabolism [64]. They provide a natural defence against pathogenic species through competition and maintenance of the mucosa. It is through their contact with the immune system that the microorganisms 
occupying the gut can elicit or prevent inflammation. They may be associated with anti-inflammatory mechanisms, stimulating regulatory cells of the immune system to inhibit inflammation [65]. On the other hand, as bacteria regulate the permeability of the intestines, certain species can promote a "leaky gut", where metabolites associated with the microbes leave the gut and enter the bloodstream. In response, the body produces cytokines and other mediators, effectively launching an inflammatory response [66]. Similarly, cells within the epithelial tissue of the gut deliver bacterial metabolites to immune cells, promoting inflammation on both a local and systemic scale. The persistence of this condition may lead to subacute or chronic inflammation, which may subsequently drive the development of diseases such as inflammatory bowel disease, diabetes or cardiovascular disease [65].

\section{Proposed Mechanisms and Relationships between the Gut Microbiota and Inflammatory Markers}

\subsection{Lipopolysaccharides}

Lipopolysaccharides (LPS), also known as endotoxin, form the key cell wall component of Gram-negative bacteria. Increased levels of LPS are observed in obesity and other metabolic disorders as well as adipose tissue inflammation and pancreatic beta-cell dysfunction [23,67-69]. Under normal conditions, the gut barrier including intestinal epithelial and mucosal layers, minimises movement of LPS from the bowels into the systemic circulation [70]. Disruption of this barrier by factors such as diet or pathogenic bacteria, may lead to LPS dislocation and movement between the junctions of the intestinal barrier into the circulation [70]. This leakiness and dysregulated permeability of the gut means macrophages can infiltrate the region, produce and activate inflammatory cytokines, leading to local inflammation [70]. Moreover, LPS binds to toll-like receptor 4 (TLR-4) found on immune cells, and in doing so can activate pro-inflammatory cascades both local to the intestine and in distant sites [67]. In a study by Cani et al. [71], mice fed a high-fat diet were found to have a high amount of LPS circulating in their bloodstreams, exhibiting endotoxaemia, however when administered antibiotics, this elevated level of LPS was not found. This demonstrates that gut microbiota induced by high fat diets release LPS, and when targeted by antibiotics, downstream effects of LPS would be prevented. Here, it is presumed that the antibiotics eliminate most of the microbiota, including LPS-secreting bacteria in locations other than the GI tract.

Upon injecting healthy human participants with LPS, Mehta et al. [72] found increased insulin resistance as insulin receptors in adipose tissue became suppressed, although pancreatic beta-cell function was not compromised. Furthermore, a study by Tian et al. [73] reported that probiotic therapy with Lactobacillus paracasei reduced and reversed the effects of LPS-associated pathology in rodents, specifically reducing type 2 diabetes-associated mechanisms such as beta-cell dysfunction. However, it is worth noting that not all members of the Lactobacillus genus have anti-diabetic properties, as in a human study it was found that Lactobacillus gasseri was elevated in those with type 2 diabetes [74].

\subsection{Short-Chain Fatty Acids}

As stated above, gut bacteria possess the capability of metabolising complex carbohydrates, otherwise undigested by the host, into SCFAs. SCFAs play a critical role in the interplay between diet, the gut microbiota and downstream activation or inhibition of inflammatory cascades. Additionally, they contribute to the homeostatic control of energy and appetite regulation through their effects on metabolic pathways [75]. Depending on the type and concentration of SCFA, their effects on inflammation differ, and SCFA levels may vary in obese and lean phenotypes [76]. In many animal studies, SCFA butyrate has been associated with a variety of roles that oppose the onset of metabolic disorders [40]. Through epigenetic interactions, butyrate promotes lipolysis and mitochondrial functioning in adipocytes, thus enabling a greater energy expenditure and preventing the onset or maintenance of obesity [77,78]. Butyrate is an anti-inflammatory metabolite that is known to inhibit the pathways that lead to the production of pro-inflammatory cytokines $[79,80]$. In a clinical study of 13 patients with Crohn's disease, oral administration of butyrate was found to alleviate inflammation 
in nine patients [81]. Additionally, butyrate minimises the risk of development of insulin resistance as it improves insulin signalling [82]. Butyrate has also been shown to minimise LPS translocation in the intestines, thus reducing LPS-associated effects [40]. Faecalibacterium prausnitzii has been identified as a butyrate-producing bacterium with an inverse relationship with different pro-inflammatory markers [83]. In obese individuals, F. prausnitzii abundance is reduced compared to individuals with healthy body weight [84].

Acetate, another SCFA, is an important molecule for the processes of lipogenesis and gluconeogenesis. Acetate can serve as a substrate for cholesterol synthesis, thus contributing to elevated serum cholesterol levels [85]. In a study of rats, contrasting with butyrate, acetate was found to correlate with greater insulin resistance and an increase in ghrelin secretion as a result of its activation of the parasympathetic nervous system [86]. As ghrelin is an appetite-stimulating hormone associated with greater food intake, acetate may consequently be linked with weight gain [86].

Although there is some consensus on SCFAs and their metabolic properties, findings have been inconsistent [87]. Regarding the potential role of acetate in obesity, a study conducted by Frost et al. [88] suggested that acetate is associated with appetite inhibition and therefore a lower risk of obesity. However, Perry et al. [86] reported that acetate was linked with an increased risk of obesity. Variation in the research participants, the employed research methods and analytical techniques may account for these observed differences. Nevertheless, there is a clear need for further research to elucidate the exact mechanisms by which SCFAs relate to changes in inflammation, microbiota composition and the subsequent development of metabolic disorders.

\subsection{Bile Acids}

Bile acids have a range of roles in the body, from enabling emulsification of lipids to allow their absorption by the body, to functioning as signalling ligands [67]. The conversion of primary bile acids to secondary bile acids is carried out by gut bacteria. Changes in the gut microbiota influence the types of secondary bile acids that are synthesised, which in turn, may affect the secretion of appetite hormones from the gut, resulting in different appetite inclinations [89].

Of particular relevance to this review is that bile acids, via activating the farnesoid $\mathrm{X}$ receptor (FXR) signalling pathway in enterocytes and adipocytes, cause inflammation [90]. Parséus et al. [20] found that mice lacking functional FXRs did not accumulate adipose tissue in the same way as mice with the receptor, suggesting that the gut microbiota may promote the onset of obesity through secondary bile acid formation.

\subsection{C-Reactive Protein}

C-reactive protein (CRP) is an acute-phase reactant associated with cardiovascular disease, type 2 diabetes and obesity [21]. When macrophages and T cells secrete interleukin (IL)-6, this molecule is subsequently released at high levels into the circulation [91]. In a study conducted by $\mathrm{Xu}$ and Song [21], the proportion of Akkermansia muciniphila declined in obese mice with elevated plasma levels of CRP. However, this does not explain whether CRP modulates the gut microbiota, or whether the gut microorganisms contribute to its elevation.

The abundance of members of genus Phascolarctobacterium has been associated with lower levels of CRP [92]. This relationship could potentially clarify why a decline in the proportion of this genus is associated with colonic inflammation [93]: Phascolarctobacterium are producers of propionate, an SCFA that inhibits pro-inflammatory cascades by suppressing the activity of pro-inflammatory regulator nuclear factor kappa-B (NFKB) (see Section 6.5) [94,95]. Similarly, the abundance of Faecalibacterium is inversely correlated with levels of CRP $[81,96]$. Thus, CRP is a downstream inflammatory marker that can be down-regulated through the effects of anti-inflammatory metabolic products of specific gut microbes. the evaluation of baseline serum and microbiota data of healthy subjects with BMI over 25 showed that those with higher CRP levels had a significantly lower abundance of bacteria from the genera Lactobacillus and Bifidobacterium, but a higher abundance of Escherichia and Bacteroides [97]. 


\subsection{Cytokines}

Cytokines are signalling molecules secreted by immune cells that affect numerous processes within the body, including immunomodulation [98]. Many transcription factors regulate the production of cytokines, however, the focus of this review will be on $\mathrm{NF} \kappa \mathrm{B}$, a regulator deemed prototypical and involved in the activation of various inflammation-related genes [99]. Cytokines are generally classified as either pro-inflammatory or anti-inflammatory in their downstream effects, although this binary classification is simplistic and does not account for the fact that specific cytokines can play opposing roles in multiple processes, and are context-dependent [100]. A detailed description of evidence related to all cytokines and the gut microbiota is beyond the scope of this review. In the following sections, we present some of the established correlations between the gut microbiota and TNF alpha and interleukin-6, the two cytokines that have been more commonly studied.

Table 1 highlights the general tendencies of various cytokines, as reported in previous studies.

Table 1. The inflammatory nature of cytokines $[98,101,102]$.

\begin{tabular}{|c|c|}
\hline Pro-inflammatory & $\begin{array}{l}\text { Interleukin-1 } \beta \\
\text { Interleukin-8 } \\
\text { Interleukin-12 } \\
\text { Interleukin-18 } \\
\text { Interleukin-23 } \\
\text { Tumour necrosis factor- } \alpha \\
\text { Monocyte Chemoattractant Protein-1 }\end{array}$ \\
\hline Anti-inflammatory & $\begin{array}{l}\text { Interleukin-10 } \\
\text { TGF- } \beta \\
\text { Interleukin-4 } \\
\text { Interleukin-27 } \\
\text { Interleukin-35 }\end{array}$ \\
\hline Variable & $\begin{array}{l}\text { Interferon- } \alpha^{*} \\
\text { Interleukin- } 6 \text { * }\end{array}$ \\
\hline
\end{tabular}

\subsubsection{Tumour Necrosis Factor-Alpha}

Tumour necrosis factor-alpha (TNF- $\alpha$ ) is a key cytokine known to drive inflammation. Elevated levels of this molecule have been shown to be associated with insulin resistance and glucose intolerance as TNF- $\alpha$ is able to activate various signalling pathways, including the mTOR pathway, making it a critical molecule in the development of metabolic disorders [104]. Gwozdziewiczová et al. [105] reported that TNF- $\alpha$ was higher in females than males suggesting that there may be sex-related differences in how TNF- $\alpha$ drives disease; however, the study had a small sample size $(n=70)$ subdivided into smaller groups based on sex, and results require confirmation in larger cohorts. In obesity, TNF- $\alpha$ is secreted by adipose tissue macrophages [106] and is linked with different gut microbial species. For example, Schirmer et al. [107] revealed that people with higher Bifidobacterium adolescentis abundance had a lower TNF- $\alpha$ production.

\subsubsection{Interleukin-6}

When adipocytes begin to function aberrantly, usually due to increased macrophage infiltration within adipose tissue, they release the cytokine IL-6 [104]. This molecule drives inflammation by promoting insulin resistance and metabolic dysregulation [108]. Various studies have examined the relationship between IL-6 and type 2 diabetes, finding IL-6 to be predictive of its onset $[109,110]$. Moreover, IL-6 is positively correlated with the abundance of Lactobacillus species [111] but it is unclear whether it is the specific gut microbial composition that results in the elevated IL-6, or the inverse. The abundance of Faecalibacterium has been negatively associated with levels of IL-6, a link that 
may be explained by the genus' production of butyrate and its consequent inhibition of NFkB [81]. Similarly, a study examining a population of obese individuals showed an inverse relationship between Faecalibacterium and IL-6 in both diabetic and non-diabetic individuals [96].

\subsection{Trimethylamine $\mathrm{N}$-Oxide (TMAO)}

Dietary choline, carnitine and betaine, compounds present in red meat, fish and other animal sources, are metabolised by gut microbes into trimethylamine (TMA), which is then converted into TMAO by the actions of host hepatic flavin monooxygenases $[112,113]$. Examples of TMA-producing bacteria include members of the genera Clostridium, Proteus and Escherichia; however, these may differ with respect to the substrates they utilise to produce TMA [114]. When present in high serum levels, TMAO has been linked with deleterious effects including endothelial dysfunction, which in turn promotes vascular inflammation, atherosclerosis and other cardiovascular disease risk factors [113,115-117]. These effects can be explained by the immunomodulatory effects of TMAO which have been reported in various animal and human studies. For instance, Seldin et al. [118] found that increased serum levels of TMAO induced a rise in the production of IL- 6 and TNF- $\alpha$ by the NF- $\mathrm{kB}$ signalling pathway in mouse and human cell cultures. Moreover, Rohrmann et al. [119] identified a positive association between TMAO levels and TNF- $\alpha$, but not IL- 6 in humans. A study in a healthy population found a positive correlation between levels of TMAO and CRP, however, it should be noted that this study also evaluated the production of TMAO in response to the ingestion of eggs [120]. A similar TMAO and CRP relationship was noted in a different study examining a population of patients with heart failure [121]. Research examining TMAO and inflammation typically utilises a sample with a specific diet (e.g., high protein diet), or with underlying chronic diseases [117,119-121]. As such, the role of the gut microbiota independent of diet is difficult to ascertain from the available evidence.

\section{The Interplay of the Gut Microbiota, Inflammation and Diseases}

Constantly heightened levels of inflammatory mediators can initiate pathological processes that may lead to several chronic disorders [65]. As depicted in Figure 3, while the microbiota is proposed to contribute to subacute systemic inflammation, it may also be shaped by the outcome, reinforcing the disease state. As such, it is difficult to determine a single causal pathway. Systemic inflammation can give rise to various conditions including metabolic syndrome, inflammatory bowel disease and cancer, and these have been associated with altered gut microbiota and studied widely in both animal and human studies $[20,23,27,71,122-124]$.

\subsection{Metabolic Syndrome and Associated Disorders}

Risk factors including insulin resistance, glucose intolerance, hyperglycaemia, high blood pressure, dyslipidaemia and obesity have all been correlated with variations in microbiota composition [122,125-129]. The collective term for these conditions is metabolic syndrome [130]. This encompasses the cluster of disorders that are precursors to type 2 diabetes mellitus (T2DM) and cardiovascular diseases [130]. 


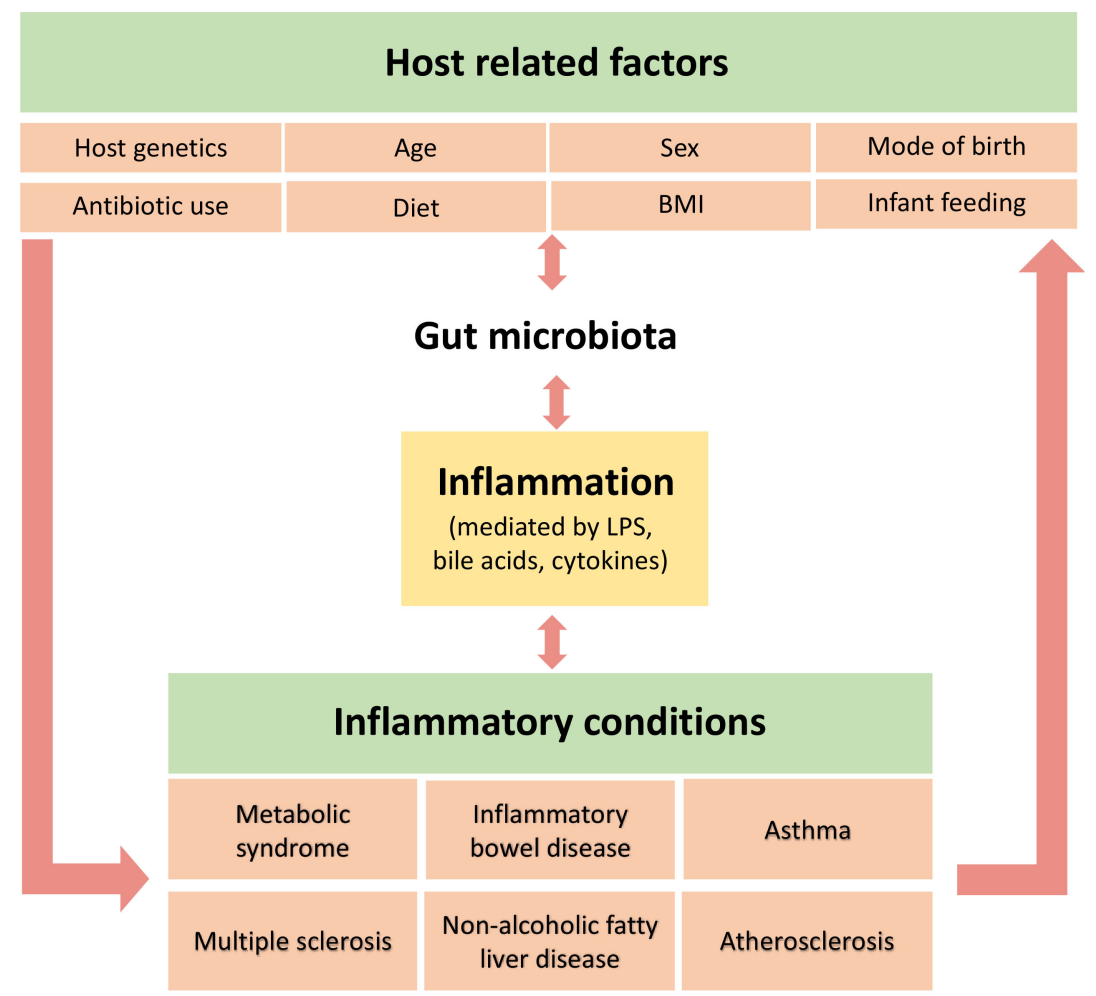

Figure 3. Interrelationships between the gut microbiota, inflammation and inflammatory conditions. The gut microbiota is shaped by various factors and has a bidirectional relationship with diet and BMI. It also has a bidirectional relationship with inflammation and depending on its composition, it can inhibit or stimulate inflammatory pathways. These, in turn, can promote the onset of various inflammatory conditions.

Studies in animals and humans have identified circulating levels of LPS as one of the key links between the gut microbiota and inflammation in metabolic syndrome [131-133]. Dislocated LPS can stimulate pro-inflammatory pathways through the activation of the receptor TLR4 on adipocytes, and the up-regulation of NF- $\mathrm{KB}$, in turn promoting insulin resistance [23,131]. Individuals with T2DM, obesity and glucose intolerance have higher circulating levels of LPS compared to those unaffected by these conditions [132]. Increased serum LPS levels are also associated with pro-inflammatory cytokines including TNF- $\alpha$ and IL-6 [133]. Circulating pro-inflammatory cytokines may inhibit insulin signalling, promoting insulin resistance [91]. LPS structurally varies among microbes with respect to its ability to activate inflammatory cascades, however notably, members of the Gram-negative phylum Proteobacteria, particularly the family Enterobacteriaceae are known to have highly immune-stimulatory LPS $[134,135]$. In one study, Enterobacteriaceae isolated from the gut microbiota of an obese human was used to develop a gnotobiotic mouse model containing only this microbe [136]. Compared to germ-free mice exposed to the same conditions, the gnotobiotic mice demonstrated elevated levels of LPS, and developed insulin resistance and obesity, whilst their germ-free counterparts exhibited normal phenotypes. This demonstrates a link between gut microbes that trigger the production of pro-inflammatory mediators, and the downstream effects of inflammatory and metabolic disorders [136]. In contrast, bacteria known to stimulate anti-inflammatory cytokines such as IL-10 and IL-22, have been associated with anti-diabetic effects in animal models [137]. For instance, the species Roseburia intestinalis is positively associated with IL-22, which has been shown to improve insulin sensitivity in mice, and is negatively associated with T2DM [137-139]. 


\subsection{Cancer}

The interplay between the gut microbiota, inflammation and cancer has been noted in several studies. Altered microbiota associated with chronic inflammation has been reported in various types of cancer including pancreas, gastric, colon, liver, breast and prostate cancer [123]. There is strong evidence for gut microbial influence on tumour formation local to the gastro-intestinal tract and on response to cancer treatment [140]. A study examining mice with colon cancer found that tumour development was reduced by the administration of antibiotics, thus indicating a pivotal role for the microbiota [141]. The gut microbiota can influence the development of tumours in numerous ways, including through the production of metabolites that cause genetic instability in host cells [142]. However, for the purpose of this review, only the links between microbiota and inflammation will be explored in the context of cancer. Pro-inflammatory micro-environments are generally associated with amplifying the development of many cancers [143]. This may clarify why long-term IBD is a strong risk factor for the development of colorectal cancer [144,145]. Dysbiosis has been noted in patients with colorectal cancer, where there is a tendency for reduced microbial diversity compared to healthy individuals, however, the taxa of microbes that are overrepresented or underrepresented are variable among cases [146-148]. One inflammation-related mechanistic link between microbiota and cancer is the NF-KB pathway, as demonstrated by a study of mice deficient of TLR-4 (a receptor of LPS and an upstream regulator of NF-kB), whereby tumour development was reduced compared to wild type mice [149]. Similarly, the gut microbiota can influence the expression of CCL5 which regulates the signalling of IL-6, enabling the proliferation of epithelial cells that can develop into tumours in colorectal cancer [150]. Further, the composition of the gut microbiota can influence the presence of pro-inflammatory-cytokine-producing immune cells, which in turn can promote a pro-inflammatory environment, considered stimulatory for tumour development [151].

\section{Limitations in Current Evidence}

Despite the increasing number of studies investigating microbiota in relation to inflammation and metabolic diseases, there remain several limitations in the current evidence base. Firstly, most studies utilise faeces to understand the gut microbiome. Faeces contain many impurities associated with the microbes, affecting the quality of the DNA yielded in the extraction phase, thus affecting interpretation of sample alpha diversity [12]. Moreover, as the gut contents change throughout the GI tract, the microbial community present in faeces is more suited to the depleted nutrient environment of the latter regions of the GI tract [152]. As such, faecal microbiota findings should be regarded as snapshots of the gut microbiota, to acknowledge the dynamic nature of this ecological community. Further, differences in stool consistency, compact or loose upon collection, may further influence interpretations of gut microbial activity and therefore must be considered. A human study found that stool consistency is a more important factor in the variation of faecal microbiota, compared to use of medication, early life events and diet [153].

Additionally, there is a need for optimising standard protocol, including faecal collection kits, transportation conditions, storage status, and DNA extraction methods, to allow for better comparisons between studies. This suggestion extends to animal studies as there are variations in methodologies between different laboratories, including diet, stress and circadian rhythms experienced by the animals [154]. For instance, the exact composition of the high-fat diet detailed for one rodent study may differ significantly from another. As different sources of fat result in different digestion outcomes, it is imperative to create a standard for how experimental animals are set up and controlled. Similarly, the environments in which rodents are kept may also play a role in composing the faecal microbiome, as it was observed that certain volatile compounds present in bedding can influence the final microbial readings [154]. Extrapolation of findings revealed in animal studies must be carried out cautiously as there are differences in human and rodent gut microbiomes. Moreover, when germ-free rodents are prepared for study, their immune system development is also altered, therefore findings must be interpreted with caution. Animal studies can broaden our understanding of this field, as they allow for 
more flexibility and additional options not available in human studies, such as the option of euthanising rodents to assess caecal microbiome samples. While useful, this creates further complications in extrapolating findings, making it difficult to ascertain potential similarities between human and rodent studies in the interplay between microbiota and inflammation.

A very small number of studies have analysed a wide range of inflammatory markers in connection with the gut microbiota. Many have outlined the changes to gut microbial composition with dysbiosis in various conditions, but the mechanisms involved including the levels of cytokines in relation to specific taxa of bacteria within certain phenotypic populations have not been thoroughly examined. In the few studies that assess this link, study design limitations including the presence of comorbidities in participants or the use of medication/s and unadjusted analyses for confounding variables such as diet and physical activity reinforce the need for more studies to confirm these associations.

\section{Conclusions and Future Directions}

Inflammation underlies many of the diseases including T2DM, cardiovascular disease, IBD and cancer which significantly contribute to global morbidity and mortality. A vast pool of studies in animals and humans have indicated a critical interplay between the gut microbiota and inflammation that could inform therapeutic intervention for the treatment of these disorders. Currently, several biomarkers of inflammation are not considered to be good predictors of chronic inflammation [155,156]. More robust biomarkers that depict the onset or degree of progression of disease may be identified through further understanding of the mechanisms bridging the gut microbiota, inflammation and morbidity.

Some microbial species have been associated strongly with anti-inflammatory roles, in particular, Faecalibacterium prausnitzii. These microbes can be further investigated in large prospective studies, which in turn may potentially inform trials in prebiotic and probiotic therapy for the amelioration of conditions underscored by inflammation. It is important to highlight that inflammatory markers are components of complex bidirectional regulatory mechanisms, and are involved in multiple overlapping processes, relating to infection and to the maintenance of homeostasis within the body. As such, the dynamic roles of cytokines, chemokines and transcription factors require further investigation by mechanistic studies.

Given the variations in methodology among much of the existing body of research in this field, there is a need for creating standard operating procedures to allow for better comparisons between studies and accelerate research and development within this area. In the future, it is likely that this field of research will rely on the collective efforts of researchers in nutrition, epidemiology, medicine, immunology and microbiology, requiring more interdisciplinary collaboration to enable a more complete understanding of the complex interactions between the host and gut microbiota.

Author Contributions: Conceptualization, N.N. evidence synthesis and writing-original draft preparation and revisions, Z.A.B., A.M. and N.N.; supervision, N.N.; writing-review and editing, Z.A.B., M.D.N., A.M. and N.N. All authors provided substantial intellectual input to the work in line with ICMJE criteria for authorship and approved the final manuscript for publication. All authors have read and agreed to the published version of the manuscript.

Funding: This research received no external funding.

Acknowledgments: A.M. is supported by a Biomedical Research Fellowship provided by the National Health and Medical Research Council (NHMRC) of Australia. N.N. is supported by a Monash Partners Health Services Fellowship.

Conflicts of Interest: The authors declare no conflict of interest.

\section{References}

1. Jack, A.G.; Martin, J.B.; Caporaso, J.G.; Janet, K.J.; Susan, V.L.; Rob, K. Current understanding of the human microbiome. Nat. Med. 2018, 24, 392. [CrossRef]

2. Petrosino, J.F. The microbiome in precision medicine: The way forward. Genome Med. 2018, 10, 12. [CrossRef] [PubMed] 
3. Ursell, L.K.; Metcalf, J.L.; Parfrey, L.W.; Knight, R. Defining the human microbiome. Nutr. Rev. 2012, 70 (Suppl. 1), S38-S44. [CrossRef] [PubMed]

4. Mobeen, F.; Sharma, V.; Tulika, P. Enterotype Variations of the Healthy Human Gut Microbiome in Different Geographical Regions. Bioinformation 2018, 14, 560-573. [CrossRef] [PubMed]

5. Qin, J.; Li, R.; Raes, J.; Arumugam, M.; Burgdorf, K.S.; Manichanh, C.; Nielsen, T.; Pons, N.; Levenez, F.; Yamada, T.; et al. A human gut microbial gene catalogue established by metagenomic sequencing. Nature 2010, 464, 59. [CrossRef] [PubMed]

6. Sender, R.; Fuchs, S.; Milo, R. Are We Really Vastly Outnumbered? Revisiting the Ratio of Bacterial to Host Cells in Humans. Cell 2016, 164, 337-340. [CrossRef] [PubMed]

7. Parks, D.H.; Chuvochina, M.; Waite, D.W.; Rinke, C.; Skarshewski, A.; Chaumeil, P.-A.; Hugenholtz, P. A standardized bacterial taxonomy based on genome phylogeny substantially revises the tree of life. Nat. Biotechnol. 2018, 36, 996. [CrossRef] [PubMed]

8. LPSN. Lactobacillus delbrueckii. Available online: https://lpsn.dsmz.de/species/lactobacillus-delbrueckii (accessed on 19 September 2020).

9. Yasuda, K.; Oh, K.; Ren, B.; Tickle, T.L.; Franzosa, E.A.; Wachtman, L.M.; Miller, A.D.; Westmoreland, S.V.; Mansfield, K.G.; Vallender, E.J.; et al. Biogeography of the intestinal mucosal and lumenal microbiome in the rhesus macaque. Cell Host Microbe 2015, 17, 385-391. [CrossRef] [PubMed]

10. National Academies of Sciences, Engineering, and Medicine. Environmental Chemicals, the Human Microbiome, and Health Risk: A Research Strategy; The National Academies Press: Washington, DC, USA, 2018; p. 122.

11. Goodrich, J.K.; Di Rienzi, S.C.; Poole, A.C.; Koren, O.; Walters, W.A.; Caporaso, J.G.; Knight, R.; Ley, R.E. Conducting a Microbiome Study. Cell 2014, 158, 250-262. [CrossRef]

12. Kumar, J.; Kumar, M.; Gupta, S.; Ahmed, V.; Bhambi, M.; Pandey, R.; Chauhan, N.S. An Improved Methodology to Overcome Key Issues in Human Fecal Metagenomic DNA Extraction. Genom. Proteom. Bioinform. 2016, 14, 371-378. [CrossRef]

13. Kuczynski, J.; Stombaugh, J.; Walters, W.A.; González, A.; Caporaso, J.G.; Knight, R. Using QIIME to analyze $16 \mathrm{~S}$ rRNA gene sequences from microbial communities. Curr. Protoc. Bioinform. 2011, 36. [CrossRef] [PubMed]

14. Wakita, Y.; Shimomura, Y.; Kitada, Y.; Yamamoto, H.; Ohashi, Y.; Matsumoto, M. Taxonomic classification for microbiome analysis, which correlates well with the metabolite milieu of the gut. BMC Microbiol. 2018, 18, 188. [CrossRef]

15. Johnson, J.S.; Spakowicz, D.J.; Hong, B.-Y.; Petersen, L.M.; Demkowicz, P.; Chen, L.; Leopold, S.R.; Hanson, B.M.; Agresta, H.O.; Gerstein, M.; et al. Evaluation of 16S rRNA gene sequencing for species and strain-level microbiome analysis. Nat. Commun. 2019, 10, 5029. [CrossRef]

16. Morgan, X.C.; Tickle, T.L.; Sokol, H.; Gevers, D.; Devaney, K.L.; Ward, D.V.; Reyes, J.A.; Shah, S.A.; LeLeiko, N.; Snapper, S.B.; et al. Dysfunction of the intestinal microbiome in inflammatory bowel disease and treatment. Genome Biol. 2012, 13, R79. [CrossRef] [PubMed]

17. Tong, M.; Jacobs, J.P.; McHardy, I.H.; Braun, J. Sampling of intestinal microbiota and targeted amplification of bacterial 16S rRNA genes for microbial ecologic analysis. Curr. Protoc. Immunol. 2014, 107. [CrossRef] [PubMed]

18. Kostic, A.D.; Howitt, M.R.; Garrett, W.S. Exploring host-microbiota interactions in animal models and humans. Genes Dev. 2013, 27, 701-718. [CrossRef] [PubMed]

19. Yi, P.; Li, L. The germfree murine animal: An important animal model for research on the relationship between gut microbiota and the host. Vet. Microbiol. 2012, 157, 1-7. [CrossRef]

20. Parséus, A.; Sommer, N.; Sommer, F.; Caesar, R.; Molinaro, A.; Ståhlman, M.; Greiner, T.U.; Perkins, R.; Bäckhed, F. Microbiota-induced obesity requires farnesoid X receptor. Gut 2017, 66, 429. [CrossRef]

21. Xu, W.; Song, Q. Abstract 19614: C-reactive Protein Re-shapes the Composition of Gut Microbiota and Causes Obesity. Circulation 2017, 136, A19614. [CrossRef]

22. Garrett, W.S.; Gallini, C.A.; Yatsunenko, T.; Michaud, M.; DuBois, A.; Delaney, M.L.; Punit, S.; Karlsson, M.; Bry, L.; Glickman, J.N.; et al. Enterobacteriaceae Act in Concert with the Gut Microbiota to Induce Spontaneous and Maternally Transmitted Colitis. Cell Host Microbe 2010, 8, 292-300. [CrossRef]

23. Cani, P.D.; Amar, J.; Iglesias, M.A.; Poggi, M.; Knauf, C.; Bastelica, D.; Neyrinck, A.M.; Fava, F.; Tuohy, K.M.; Chabo, C.; et al. Metabolic endotoxemia initiates obesity and insulin resistance. Diabetes 2007, 56, 1761-1772. [CrossRef] [PubMed] 
24. Hayashi, A.; Sato, T.; Kamada, N.; Mikami, Y.; Matsuoka, K.; Hisamatsu, T.; Hibi, T.; Roers, A.; Yagita, H.; Ohteki, T.; et al. A single strain of Clostridium butyricum induces intestinal IL-10-producing macrophages to suppress acute experimental colitis in mice. Cell Host Microbe 2013, 13, 711-722. [CrossRef] [PubMed]

25. Guittar, J.; Shade, A.; Litchman, E. Trait-based community assembly and succession of the infant gut microbiome. Nat. Commun. 2019, 10. [CrossRef] [PubMed]

26. Larsen, O.F.A.; Claassen, E. The mechanistic link between health and gut microbiota diversity. Sci. Rep. 2018, 8, 2183. [CrossRef] [PubMed]

27. Sommer, F.; Anderson, J.M.; Bharti, R.; Raes, J.; Rosenstiel, P. The resilience of the intestinal microbiota influences health and disease. Nat. Rev. Microbiol. 2017, 15, 630-638. [CrossRef] [PubMed]

28. Sordillo, J.E.; Zhou, Y.; McGeachie, M.J.; Ziniti, J.; Lange, N.; Laranjo, N.; Savage, J.R.; Carey, V.; Connor, G.; Sandel, M.; et al. Factors influencing the infant gut microbiome at age 3-6 months: Findings from the ethnically diverse Vitamin D Antenatal Asthma Reduction Trial (VDAART). J. Allergy Clin. Immunol. 2017, 139, 482-491.e14. [CrossRef] [PubMed]

29. Dominguez-Bello, M.G.; Costello, E.K.; Contreras, M.; Magris, M.; Hidalgo, G.; Fierer, N.; Knight, R. Delivery mode shapes the acquisition and structure of the initial microbiota across multiple body habitats in newborns. Proc. Natl. Acad. Sci. USA 2010, 107, 11971-11975. [CrossRef]

30. Matamoros, S.; Gras-Leguen, C.; Le Vacon, F.; Potel, G.; de La Cochetiere, M.F. Development of intestinal microbiota in infants and its impact on health. Trends Microbiol. 2013, 21, 167-173. [CrossRef]

31. Chu, D.M.; Ma, J.; Prince, A.L.; Antony, K.M.; Seferovic, M.D.; Aagaard, K.M. Maturation of the infant microbiome community structure and function across multiple body sites and in relation to mode of delivery. Nat. Med. 2017, 23, 314-326. [CrossRef]

32. Backhed, F.; Roswall, J.; Peng, Y.; Feng, Q.; Jia, H.; Kovatcheva-Datchary, P.; Li, Y.; Xia, Y.; Xie, H.; Zhong, H.; et al. Dynamics and Stabilization of the Human Gut Microbiome during the First Year of Life. Cell Host Microbe 2015, 17, 690-703. [CrossRef]

33. Negele, K.; Heinrich, J.; Borte, M.; von Berg, A.; Schaaf, B.; Lehmann, I.; Wichmann, H.E.; Bolte, G. Mode of delivery and development of atopic disease during the first 2 years of life. Pediatric Allergy Immunol. Off. Publ. Eur. Soc. Pediatric Allergy Immunol. 2004, 15, 48-54. [CrossRef]

34. Wampach, L.; Heintz-Buschart, A.; Fritz, J.V.; Ramiro-Garcia, J.; Habier, J.; Herold, M.; Narayanasamy, S.; Kaysen, A.; Hogan, A.H.; Bindl, L.; et al. Birth mode is associated with earliest strain-conferred gut microbiome functions and immunostimulatory potential. Nat. Commun. 2018, 9, 5091. [CrossRef] [PubMed]

35. Patel, S.; Goyal, A. The current trends and future perspectives of prebiotics research: A review. 3 Biotech 2012, 2, 115-125. [CrossRef]

36. Timmerman, H.M.; Rutten, N.B.M.M.; Boekhorst, J.; Saulnier, D.M.; Kortman, G.A.M.; Contractor, N.; Kullen, M.; Floris, E.; Harmsen, H.J.M.; Vlieger, A.M.; et al. Intestinal colonisation patterns in breastfed and formula-fed infants during the first 12 weeks of life reveal sequential microbiota signatures. Sci. Rep. 2017, 7, 8327. [CrossRef]

37. Chen, J.; He, X.; Huang, J. Diet effects in gut microbiome and obesity. J. Food Sci. 2014, 79, R442-R451. [CrossRef] [PubMed]

38. David, L.A.; Maurice, C.F.; Carmody, R.N.; Gootenberg, D.B.; Button, J.E.; Wolfe, B.E.; Ling, A.V.; Devlin, A.S.; Varma, Y.; Fischbach, M.A.; et al. Diet rapidly and reproducibly alters the human gut microbiome. Nature 2014, 505, 559-563. [CrossRef]

39. Pak, H.H.; Cummings, N.E.; Green, C.L.; Brinkman, J.A.; Yu, D.; Tomasiewicz, J.L.; Yang, S.E.; Boyle, C.; Konon, E.N.; Ong, I.M.; et al. The Metabolic Response to a Low Amino Acid Diet is Independent of Diet-Induced Shifts in the Composition of the Gut Microbiome. Sci. Rep. 2019, 9. [CrossRef]

40. Hartstra, A.V.; Bouter, K.E.C.; Bäckhed, F.; Nieuwdorp, M. Insights into the Role of the Microbiome in Obesity and Type 2 Diabetes. Diabetes Care 2015, 38, 159. [CrossRef] [PubMed]

41. De Filippo, C.; Cavalieri, D.; Di Paola, M.; Ramazzotti, M.; Poullet, J.B.; Massart, S.; Collini, S.; Pieraccini, G.; Lionetti, P. Impact of diet in shaping gut microbiota revealed by a comparative study in children from Europe and rural Africa. Proc. Natl. Acad. Sci. USA 2010, 107, 14691-14696. [CrossRef]

42. Singh, R.K.; Chang, H.W.; Yan, D.; Lee, K.M.; Ucmak, D.; Wong, K.; Abrouk, M.; Farahnik, B.; Nakamura, M.; Zhu, T.H.; et al. Influence of diet on the gut microbiome and implications for human health. J. Transl. Med. 2017, 15, 73. [CrossRef] [PubMed] 
43. Zinöcker, M.K.; Lindseth, I.A. The Western Diet-Microbiome-Host Interaction and Its Role in Metabolic Disease. Nutrients 2018, 10, 365. [CrossRef] [PubMed]

44. Odamaki, T.; Kato, K.; Sugahara, H.; Hashikura, N.; Takahashi, S.; Xiao, J.-Z.; Abe, F.; Osawa, R. Age-related changes in gut microbiota composition from newborn to centenarian: A cross-sectional study. BMC Microbiol. 2016, 16, 90. [CrossRef] [PubMed]

45. Nagpal, R.; Mainali, R.; Ahmadi, S.; Wang, S.; Singh, R.; Kavanagh, K.; Kitzman, D.W.; Kushugulova, A.; Marotta, F.; Yadav, H. Gut microbiome and aging: Physiological and mechanistic insights. Nutr. Healthy Aging 2018, 4, 267-285. [CrossRef]

46. Taneja, V. Chapter 39-Microbiome: Impact of Gender on Function \& Characteristics of Gut Microbiome. In Principles of Gender-Specific Medicine (Third Edition); Legato, M.J., Ed.; Academic Press: San Diego, CA, USA, 2017; pp. 569-583.

47. Baars, A.; Oosting, A.; Lohuis, M.; Koehorst, M.; El Aidy, S.; Hugenholtz, F.; Smidt, H.; Mischke, M.; Boekschoten, M.V.; Verkade, H.J.; et al. Sex differences in lipid metabolism are affected by presence of the gut microbiota. Sci. Rep. 2018, 8, 13426. [CrossRef]

48. Haro, C.; Rangel-Zúñiga, O.A.; Alcalá-Díaz, J.F.; Gómez-Delgado, F.; Pérez-Martínez, P.; Delgado-Lista, J.; Quintana-Navarro, G.M.; Landa, B.B.; Navas-Cortés, J.A.; Tena-Sempere, M.; et al. Intestinal Microbiota Is Influenced by Gender and Body Mass Index. PLoS ONE 2016, 11, e0154090. [CrossRef] [PubMed]

49. RodrÍguez, J.M.; Murphy, K.; Stanton, C.; Ross, R.P.; Kober, O.I.; Juge, N.; Avershina, E.; Rudi, K.; Narbad, A.; Jenmalm, M.C.; et al. The composition of the gut microbiota throughout life, with an emphasis on early life. Microb. Ecol. Health Dis. 2015, 26, 26050. [CrossRef]

50. Yun, Y.; Kim, H.-N.; Kim, S.E.; Heo, S.G.; Chang, Y.; Ryu, S.; Shin, H.; Kim, H.-L. Comparative analysis of gut microbiota associated with body mass index in a large Korean cohort. BMC Microbiol. 2017, 17, 151. [CrossRef]

51. Ley, R.E.; Turnbaugh, P.J.; Klein, S.; Gordon, J.I. Human gut microbes associated with obesity. Nature 2006, 444, 1022-1023. [CrossRef]

52. Lim, M.Y.; You, H.J.; Yoon, H.S.; Kwon, B.; Lee, J.Y.; Lee, S.; Song, Y.-M.; Lee, K.; Sung, J.; Ko, G. The effect of heritability and host genetics on the gut microbiota and metabolic syndrome. Gut 2017, 66, 1031. [CrossRef]

53. Goodrich, J.K.; Davenport, E.R.; Clark, A.G.; Ley, R.E. The Relationship Between the Human Genome and Microbiome Comes into View. Annu. Rev. Genet. 2017, 51, 413-433. [CrossRef] [PubMed]

54. Russell, J.T.; Roesch, L.F.W.; Ördberg, M.; Ilonen, J.; Atkinson, M.A.; Schatz, D.A.; Triplett, E.W.; Ludvigsson, J. Genetic risk for autoimmunity is associated with distinct changes in the human gut microbiome. Nat. Commun. 2019, 10, 3621. [CrossRef]

55. Chen, B.; Li, J.; He, C.; Li, D.; Tong, W.; Zou, Y.; Xu, W. Role of HLA-B27 in the pathogenesis of ankylosing spondylitis (Review). Mol. Med. Rep. 2017, 15, 1943-1951. [CrossRef] [PubMed]

56. Asquith, M.; Sternes, P.R.; Costello, M.E.; Karstens, L.; Diamond, S.; Martin, T.M.; Li, Z.; Marshall, M.S.; Spector, T.D.; le Cao, K.A.; et al. HLA Alleles Associated with Risk of Ankylosing Spondylitis and Rheumatoid Arthritis Influence the Gut Microbiome. Arthritis Rheumatol. 2019, 71, 1642-1650. [CrossRef]

57. Rothschild, D.; Weissbrod, O.; Barkan, E.; Kurilshikov, A.; Korem, T.; Zeevi, D.; Costea, P.I.; Godneva, A.; Kalka, I.N.; Bar, N.; et al. Environment dominates over host genetics in shaping human gut microbiota. Nature 2018, 555, 210-215. [CrossRef]

58. Francino, M.P. Antibiotics and the Human Gut Microbiome: Dysbioses and Accumulation of Resistances. Front. Microbiol. 2016, 6, 1543. [CrossRef] [PubMed]

59. Bien, J.; Palagani, V.; Bozko, P. The intestinal microbiota dysbiosis and Clostridium difficile infection: Is there a relationship with inflammatory bowel disease? Ther. Adv. Gastroenterol. 2012, 6, 53-68. [CrossRef]

60. Murphy, R.; Stewart, A.W.; Braithwaite, I.; Beasley, R.; Hancox, R.J.; Mitchell, E.A. Antibiotic treatment during infancy and increased body mass index in boys: An international cross-sectional study. Int. J. Obes. 2014, 38, 1115. [CrossRef] [PubMed]

61. Clarke, G.; Stilling, R.M.; Kennedy, P.J.; Stanton, C.; Cryan, J.F.; Dinan, T.G. Minireview: Gut Microbiota: The Neglected Endocrine Organ. Mol. Endocrinol. 2014, 28, 1221-1238. [CrossRef] [PubMed]

62. Flint, H.J.; Scott, K.P.; Duncan, S.H.; Louis, P.; Forano, E. Microbial degradation of complex carbohydrates in the gut. Gut Microbes 2012, 3, 289-306. [CrossRef] [PubMed]

63. Tan, J.; McKenzie, C.; Potamitis, M.; Thorburn, A.N.; Mackay, C.R.; Macia, L. The role of short-chain fatty acids in health and disease. Adv. Immunol. 2014, 121, 91-119. [CrossRef] [PubMed] 
64. Jandhyala, S.M.; Talukdar, R.; Subramanyam, C.; Vuyyuru, H.; Sasikala, M.; Nageshwar Reddy, D. Role of the normal gut microbiota. World J. Gastroenterol. 2015, 21, 8787-8803. [CrossRef] [PubMed]

65. Hakansson, A.; Molin, G. Gut microbiota and inflammation. Nutrients 2011, 3, 637-682. [CrossRef] [PubMed]

66. Brandsma, E.; Kloosterhuis Niels, J.; Koster, M.; Dekker Daphne, C.; Gijbels Marion, J.J.; van der Velden, S.; Ríos-Morales, M.; van Faassen Martijn, J.R.; Loreti Marco, G.; de Bruin, A.; et al. A Proinflammatory Gut Microbiota Increases Systemic Inflammation and Accelerates Atherosclerosis. Circ. Res. 2019, 124, 94-100. [CrossRef]

67. Janssen, A.W.F.; Kersten, S. Potential mediators linking gut bacteria to metabolic health: A critical view. J. Physiol. 2017, 595, 477-487. [CrossRef]

68. Davis, C.D. The Gut Microbiome and Its Role in Obesity. Nutr. Today 2016, 51, 167-174. [CrossRef]

69. Greiner, T.; Bäckhed, F. Effects of the gut microbiota on obesity and glucose homeostasis. Trends Endocrinol. Metab. 2011, 22, 117-123. [CrossRef] [PubMed]

70. Ghosh, S.S.; Wang, J.; Yannie, P.J.; Ghosh, S. Intestinal Barrier Dysfunction, LPS Translocation, and Disease Development. J. Endocr. Soc. 2020, 4. [CrossRef] [PubMed]

71. Cani, P.D.; Bibiloni, R.; Knauf, C.; Waget, A.; Neyrinck, A.M.; Delzenne, N.M.; Burcelin, R. Changes in gut microbiota control metabolic endotoxemia-induced inflammation in high-fat diet-induced obesity and diabetes in mice. Diabetes 2008, 57, 1470-1481. [CrossRef] [PubMed]

72. Mehta, N.N.; McGillicuddy, F.C.; Anderson, P.D.; Hinkle, C.C.; Shah, R.; Pruscino, L.; Tabita-Martinez, J.; Sellers, K.F.; Rickels, M.R.; Reilly, M.P. Experimental endotoxemia induces adipose inflammation and insulin resistance in humans. Diabetes 2010, 59, 172-181. [CrossRef] [PubMed]

73. Tian, P.; Li, B.; He, C.; Song, W.; Hou, A.; Tian, S.; Meng, X.; Li, K.; Shan, Y. Antidiabetic (type 2) effects of Lactobacillus G15 and Q14 in rats through regulation of intestinal permeability and microbiota. Food Funct. 2016, 7, 3789-3797. [CrossRef]

74. Karlsson, F.H.; Tremaroli, V.; Nookaew, I.; Bergstrom, G.; Behre, C.J.; Fagerberg, B.; Nielsen, J.; Backhed, F. Gut metagenome in European women with normal, impaired and diabetic glucose control. Nature 2013, 498, 99-103. [CrossRef] [PubMed]

75. Hu, J.; Lin, S.; Zheng, B.; Cheung, P.C.K. Short-chain fatty acids in control of energy metabolism. Crit. Rev. Food Sci. Nutr. 2018, 58, 1243-1249. [CrossRef] [PubMed]

76. Ernsting, C.; Dombrowski, S.U.; Oedekoven, M.; O'Sullivan, J.L.; Kanzler, E.; Kuhlmey, A.; Gellert, P. Using smartphones and health apps to change and manage health behaviors: A population-based survey. J. Med. Internet Res. 2017, 19. [CrossRef] [PubMed]

77. Jia, Y.; Hong, J.; Li, H.; Hu, Y.; Jia, L.; Cai, D.; Zhao, R. Butyrate stimulates adipose lipolysis and mitochondrial oxidative phosphorylation through histone hyperacetylation-associated $\beta 3$-adrenergic receptor activation in high-fat diet-induced obese mice. Exp. Physiol. 2017, 102, 273-281. [CrossRef] [PubMed]

78. Turnbaugh, P.J.; Gordon, J.I. The core gut microbiome, energy balance and obesity. J. Physiol. 2009, 587, 4153-4158. [CrossRef]

79. Segain, J.P.; Raingeard de la Blétière, D.; Bourreille, A.; Leray, V.; Gervois, N.; Rosales, C.; Ferrier, L.; Bonnet, C.; Blottière, H.M.; Galmiche, J.P. Butyrate inhibits inflammatory responses through NFkappaB inhibition: Implications for Crohn's disease. Gut 2000, 47, 397-403. [CrossRef] [PubMed]

80. Lührs, H.; Gerke, T.; Schauber, J.; Dusel, G.; Melcher, R.; Scheppach, W.; Menzel, T. Cytokine-activated degradation of inhibitory kappaB protein alpha is inhibited by the short-chain fatty acid butyrate. Int. J. Colorectal Dis. 2001, 16, 195-201. [CrossRef] [PubMed]

81. Di Sabatino, A.; Cazzola, P.; Ciccocioppo, R.; Morera, R.; Biancheri, P.; Rovedatti, L.; Cantoro, L.; Vanoli, A.; Tinozzi, F.P.; Tinozzi, S.; et al. Efficacy of butyrate in the treatment of mild to moderate Crohn's disease. Dig. Liver Dis. Suppl. 2007, 1, 31-35. [CrossRef]

82. Gao, Z.; Yin, J.; Zhang, J.; Ward, R.E.; Martin, R.J.; Lefevre, M.; Cefalu, W.T.; Ye, J. Butyrate improves insulin sensitivity and increases energy expenditure in mice. Diabetes 2009, 58, 1509-1517. [CrossRef]

83. van den Munckhof, I.C.L.; Kurilshikov, A.; Ter Horst, R.; Riksen, N.P.; Joosten, L.A.B.; Zhernakova, A.; Fu, J.; Keating, S.T.; Netea, M.G.; de Graaf, J.; et al. Role of gut microbiota in chronic low-grade inflammation as potential driver for atherosclerotic cardiovascular disease: A systematic review of human studies. Obes. Rev. Off. J. Int. Assoc. Study Obes. 2018, 19, 1719-1734. [CrossRef]

84. Ryan, P.M.; Delzenne, N.M. Chapter 18-Gut Microbiota and Metabolism. In The Gut-Brain Axis; Hyland, N., Stanton, C., Eds.; Academic Press: Cambridge, MA, USA, 2016; pp. 391-401. 
85. Schwiertz, A.; Taras, D.; Schafer, K.; Beijer, S.; Bos, N.A.; Donus, C.; Hardt, P.D. Microbiota and SCFA in lean and overweight healthy subjects. Obesity (Silver Spring) 2010, 18, 190-195. [CrossRef] [PubMed]

86. Perry, R.J.; Peng, L.; Barry, N.A.; Cline, G.W.; Zhang, D.; Cardone, R.L.; Petersen, K.F.; Kibbey, R.G.; Goodman, A.L.; Shulman, G.I. Acetate mediates a microbiome-brain- $\beta$-cell axis to promote metabolic syndrome. Nature 2016, 534, 213-217. [CrossRef] [PubMed]

87. Hernández, M.A.G.; Canfora, E.E.; Jocken, J.W.E.; Blaak, E.E. The Short-Chain Fatty Acid Acetate in Body Weight Control and Insulin Sensitivity. Nutrients 2019, 11, 1943. [CrossRef] [PubMed]

88. Frost, G.; Sleeth, M.L.; Sahuri-Arisoylu, M.; Lizarbe, B.; Cerdan, S.; Brody, L.; Anastasovska, J.; Ghourab, S.; Hankir, M.; Zhang, S.; et al. The short-chain fatty acid acetate reduces appetite via a central homeostatic mechanism. Nat. Commun. 2014, 5, 3611. [CrossRef] [PubMed]

89. Long, S.L.; Gahan, C.G.M.; Joyce, S.A. Interactions between gut bacteria and bile in health and disease. Mol. Asp. Med. 2017, 56, 54-65. [CrossRef] [PubMed]

90. Just, S.; Mondot, S.; Ecker, J.; Wegner, K.; Rath, E.; Gau, L.; Streidl, T.; Hery-Arnaud, G.; Schmidt, S.; Lesker, T.R.; et al. The gut microbiota drives the impact of bile acids and fat source in diet on mouse metabolism. Microbiome 2018, 6, 134. [CrossRef] [PubMed]

91. Patel, H.; H Patel, V. Inflammation and Metabolic Syndrome: An Overview. Curr Res Nutr Food Sci. 2015, 3, 263-268. [CrossRef]

92. Citronberg, J.S.; Curtis, K.R.; White, E.; Newcomb, P.A.; Newton, K.; Atkinson, C.; Song, X.; Lampe, J.W.; Hullar, M.A. Association of gut microbial communities with plasma lipopolysaccharide-binding protein (LBP) in premenopausal women. ISME J. 2018, 12, 1631-1641. [CrossRef]

93. Bajer, L.; Kverka, M.; Kostovcik, M.; Macinga, P.; Dvorak, J.; Stehlikova, Z.; Brezina, J.; Wohl, P.; Spicak, J.; Drastich, P. Distinct gut microbiota profiles in patients with primary sclerosing cholangitis and ulcerative colitis. World J. Gastroenterol. 2017, 23, 4548-4558. [CrossRef] [PubMed]

94. Wu, F.; Guo, X.; Zhang, J.; Zhang, M.; Ou, Z.; Peng, Y. Phascolarctobacterium faecium abundant colonization in human gastrointestinal tract. Exp. Ther. Med. 2017, 14, 3122-3126. [CrossRef]

95. Tedelind, S.; Westberg, F.; Kjerrulf, M.; Vidal, A. Anti-inflammatory properties of the short-chain fatty acids acetate and propionate: A study with relevance to inflammatory bowel disease. World J. Gastroenterol. 2007, 13, 2826-2832. [CrossRef]

96. Furet, J.P.; Kong, L.C.; Tap, J.; Poitou, C.; Basdevant, A.; Bouillot, J.L.; Mariat, D.; Corthier, G.; Doré, J.; Henegar, C.; et al. Differential adaptation of human gut microbiota to bariatric surgery-induced weight loss: Links with metabolic and low-grade inflammation markers. Diabetes 2010, 59, 3049-3057. [CrossRef]

97. Rajkumar, H.; Mahmood, N.; Kumar, M.; Varikuti, S.R.; Challa, H.R.; Myakala, S.P. Effect of probiotic (VSL\#3) and omega-3 on lipid profile, insulin sensitivity, inflammatory markers, and gut colonization in overweight adults: A randomized, controlled trial. Mediat. Inflamm. 2014, 2014, 348959. [CrossRef]

98. Arango Duque, G.; Descoteaux, A. Macrophage cytokines: Involvement in immunity and infectious diseases. Front. Immunol. 2014, 5, 491. [CrossRef]

99. Lawrence, T. The nuclear factor NF-kappaB pathway in inflammation. Cold Spring Harb. Perspect. Biol. 2009, 1, a001651. [CrossRef] [PubMed]

100. Cavaillon, J.M. Pro- versus anti-inflammatory cytokines: Myth or reality. Cell. Mol. Biol. (Noisy-Le-Grand Fr.) 2001, 47, 695-702.

101. Tilg, H.; Peschel, C. Interferon-alpha and its effects on the cytokine cascade: A pro- and anti-inflammatory cytokine. Leuk. Lymphoma 1996, 23, 55-60. [CrossRef]

102. Deshmane, S.L.; Kremlev, S.; Amini, S.; Sawaya, B.E. Monocyte chemoattractant protein-1 (MCP-1): An overview. J. Interferon Cytokine Res. 2009, 29, 313-326. [CrossRef]

103. Tanaka, T.; Narazaki, M.; Kishimoto, T. IL-6 in inflammation, immunity, and disease. Cold Spring Harb. Perspect. Biol. 2014, 6, a016295. [CrossRef]

104. Srikanthan, K.; Feyh, A.; Visweshwar, H.; Shapiro, J.I.; Sodhi, K. Systematic Review of Metabolic Syndrome Biomarkers: A Panel for Early Detection, Management, and Risk Stratification in the West Virginian Population. Int. J. Med. Sci. 2016, 13, 25-38. [CrossRef] [PubMed]

105. Gwozdziewiczova, S.; Lichnovska, R.; Ben Yahia, R.; Chlup, R.; Hrebicek, J. TNF-alpha in the development of insulin resistance and other disorders in metabolic syndrome. Biomed. Pap. Med. Fac. Univ. Palacky Olomouc Czechoslov. 2005, 149, 109-117. [CrossRef] 
106. Weisberg, S.P.; McCann, D.; Desai, M.; Rosenbaum, M.; Leibel, R.L.; Ferrante, A.W., Jr. Obesity is associated with macrophage accumulation in adipose tissue. J. Clin. Investig. 2003, 112, 1796-1808. [CrossRef] [PubMed]

107. Schirmer, M.; Smeekens, S.P.; Vlamakis, H.; Jaeger, M.; Oosting, M.; Franzosa, E.A.; Ter Horst, R.; Jansen, T.; Jacobs, L.; Bonder, M.J.; et al. Linking the Human Gut Microbiome to Inflammatory Cytokine Production Capacity. Cell 2016, 167, 1125-1136.e8. [CrossRef]

108. Weiss, T.W.; Arnesen, H.; Seljeflot, I. Components of the interleukin-6 transsignalling system are associated with the metabolic syndrome, endothelial dysfunction and arterial stiffness. Metab. Clin. Exp. 2013, 62, 1008-1013. [CrossRef] [PubMed]

109. Bertoni, A.G.; Burke, G.L.; Owusu, J.A.; Carnethon, M.R.; Vaidya, D.; Barr, R.G.; Jenny, N.S.; Ouyang, P.; Rotter, J.I. Inflammation and the incidence of type 2 diabetes: The Multi-Ethnic Study of Atherosclerosis (MESA). Diabetes Care 2010, 33, 804-810. [CrossRef]

110. Pradhan, A.D.; Manson, J.E.; Rifai, N.; Buring, J.E.; Ridker, P.M. C-reactive protein, interleukin 6, and risk of developing type 2 diabetes mellitus. JAMA 2001, 286, 327-334. [CrossRef]

111. Cooper, D.; Kim, E.B.; Marco, M.; Rust, B.; Welch, L.; Horn, W.; Martin, R.; Keim, N. Relationship between Human Gut Microbiota and Interleukin 6 Levels in Overweight and Obese Adults. FASEB J. 2016, 30, 146. [CrossRef]

112. Janeiro, M.H.; Ramírez, M.J.; Milagro, F.I.; Martínez, J.A.; Solas, M. Implication of Trimethylamine N-Oxide (TMAO) in Disease: Potential Biomarker or New Therapeutic Target. Nutrients 2018, 10, 1398. [CrossRef] [PubMed]

113. Koeth, R.A.; Wang, Z.; Levison, B.S.; Buffa, J.A.; Org, E.; Sheehy, B.T.; Britt, E.B.; Fu, X.; Wu, Y.; Li, L.; et al. Intestinal microbiota metabolism of L-carnitine, a nutrient in red meat, promotes atherosclerosis. Nat. Med. 2013, 19, 576-585. [CrossRef]

114. Fennema, D.; Phillips, I.R.; Shephard, E.A. Trimethylamine and Trimethylamine N-Oxide, a Flavin-Containing Monooxygenase 3 (FMO3)-Mediated Host-Microbiome Metabolic Axis Implicated in Health and Disease. Drug Metab. Dispos. Biol. Fate Chem. 2016, 44, 1839-1850. [CrossRef] [PubMed]

115. Ma, G.; Pan, B.; Chen, Y.; Guo, C.; Zhao, M.; Zheng, L.; Chen, B. Trimethylamine N-oxide in atherogenesis: Impairing endothelial self-repair capacity and enhancing monocyte adhesion. Biosci. Rep. 2017, 37. [CrossRef] [PubMed]

116. Wang, Z.; Klipfell, E.; Bennett, B.J.; Koeth, R.; Levison, B.S.; Dugar, B.; Feldstein, A.E.; Britt, E.B.; Fu, X.; Chung, Y.M.; et al. Gut flora metabolism of phosphatidylcholine promotes cardiovascular disease. Nature 2011, 472, 57-63. [CrossRef] [PubMed]

117. Al-Obaide, M.A.I.; Singh, R.; Datta, P.; Rewers-Felkins, K.A.; Salguero, M.V.; Al-Obaidi, I.; Kottapalli, K.R.; Vasylyeva, T.L. Gut Microbiota-Dependent Trimethylamine-N-oxide and Serum Biomarkers in Patients with T2DM and Advanced CKD. J. Clin. Med. 2017, 6, 86. [CrossRef] [PubMed]

118. Seldin, M.M.; Meng, Y.; Qi, H.; Zhu, W.; Wang, Z.; Hazen, S.L.; Lusis, A.J.; Shih, D.M. Trimethylamine N-Oxide Promotes Vascular Inflammation Through Signaling of Mitogen-Activated Protein Kinase and Nuclear Factor-kB. J. Am. Heart Assoc. 2016, 5. [CrossRef]

119. Rohrmann, S.; Linseisen, J.; Allenspach, M.; von Eckardstein, A.; Müller, D. Plasma Concentrations of Trimethylamine-N-oxide Are Directly Associated with Dairy Food Consumption and Low-Grade Inflammation in a German Adult Population. J. Nutr. 2015, 146, 283-289. [CrossRef] [PubMed]

120. Miller, C.A.; Corbin, K.D.; da Costa, K.A.; Zhang, S.; Zhao, X.; Galanko, J.A.; Blevins, T.; Bennett, B.J.; O'Connor, A.; Zeisel, S.H. Effect of egg ingestion on trimethylamine-N-oxide production in humans: A randomized, controlled, dose-response study. Am. J. Clin. Nutr. 2014, 100, 778-786. [CrossRef]

121. Tang, W.H.; Wang, Z.; Fan, Y.; Levison, B.; Hazen, J.E.; Donahue, L.M.; Wu, Y.; Hazen, S.L. Prognostic value of elevated levels of intestinal microbe-generated metabolite trimethylamine-N-oxide in patients with heart failure: Refining the gut hypothesis. J. Am. Coll. Cardiol. 2014, 64, 1908-1914. [CrossRef]

122. Jiao, N.; Baker, S.S.; Nugent, C.A.; Tsompana, M.; Cai, L.; Wang, Y.; Buck, M.J.; Genco, R.J.; Baker, R.D.; Zhu, R.; et al. Gut microbiome may contribute to insulin resistance and systemic inflammation in obese rodents: A meta-analysis. Physiol. Genom. 2018, 50, 244-254. [CrossRef]

123. Armstrong, H.; Bording-Jorgensen, M.; Dijk, S.; Wine, E. The Complex Interplay between Chronic Inflammation, the Microbiome, and Cancer: Understanding Disease Progression and What We Can Do to Prevent It. Cancers 2018, 10, 83. [CrossRef] 
124. Francescone, R.; Hou, V.; Grivennikov, S.I. Microbiome, inflammation, and cancer. Cancer J. (Sudbury Mass) 2014, 20, 181-189. [CrossRef]

125. Zhang, X.; Shen, D.; Fang, Z.; Jie, Z.; Qiu, X.; Zhang, C.; Chen, Y.; Ji, L. Human Gut Microbiota Changes Reveal the Progression of Glucose Intolerance. PLoS ONE 2013, 8, e71108. [CrossRef]

126. Mell, B.; Jala, V.R.; Mathew, A.V.; Byun, J.; Waghulde, H.; Zhang, Y.; Haribabu, B.; Vijay-Kumar, M.; Pennathur, S.; Joe, B. Evidence for a link between gut microbiota and hypertension in the Dahl rat. Physiol. Genom. 2015, 47, 187-197. [CrossRef] [PubMed]

127. Junjie, Q.; Yingrui, L.; Zhiming, C.; Shenghui, L.; Jianfeng, Z.; Fan, Z.; Suisha, L.; Wenwei, Z.; Yuanlin, G.; Dongqian, S.; et al. A metagenome-wide association study of gut microbiota in type 2 diabetes. Nature 2012, 490, 55. [CrossRef]

128. Castaner, O.; Goday, A.; Park, Y.-M.; Lee, S.-H.; Magkos, F.; Shiow, S.-A.T.E.; Schröder, H. The Gut Microbiome Profile in Obesity: A Systematic Review. Int. J. Endocrinol. 2018, 2018, 4095789. [CrossRef]

129. Caesar, R.; Nygren, H.; Oresic, M.; Backhed, F. Interaction between dietary lipids and gut microbiota regulates hepatic cholesterol metabolism. J. Lipid Res. 2016, 57, 474-481. [CrossRef]

130. Mazidi, M.; Rezaie, P.; Kengne, A.P.; Mobarhan, M.G.; Ferns, G.A. Gut microbiome and metabolic syndrome. Diabetes Metab. Syndr. Clin. Res. Rev. 2016, 10, S150-S157. [CrossRef] [PubMed]

131. Chung, S.; Lapoint, K.; Martinez, K.; Kennedy, A.; Boysen Sandberg, M.; McIntosh, M.K. Preadipocytes mediate lipopolysaccharide-induced inflammation and insulin resistance in primary cultures of newly differentiated human adipocytes. Endocrinology 2006, 147, 5340-5351. [CrossRef]

132. Harte, A.L.; Varma, M.C.; Tripathi, G.; McGee, K.C.; Al-Daghri, N.M.; Al-Attas, O.S.; Sabico, S.; O’Hare, J.P.; Ceriello, A.; Saravanan, P.; et al. High fat intake leads to acute postprandial exposure to circulating endotoxin in type 2 diabetic subjects. Diabetes Care 2012, 35, 375-382. [CrossRef] [PubMed]

133. Ghanim, H.; Abuaysheh, S.; Sia, C.L.; Korzeniewski, K.; Chaudhuri, A.; Fernandez-Real, J.M.; Dandona, P. Increase in plasma endotoxin concentrations and the expression of Toll-like receptors and suppressor of cytokine signaling-3 in mononuclear cells after a high-fat, high-carbohydrate meal: Implications for insulin resistance. Diabetes Care 2009, 32, 2281-2287. [CrossRef]

134. Erridge, C.; Duncan, S.H.; Bereswill, S.; Heimesaat, M.M. The induction of colitis and ileitis in mice is associated with marked increases in intestinal concentrations of stimulants of TLRs 2, 4, and 5. PLoS ONE 2010, 5, e9125. [CrossRef]

135. Hiippala, K.; Jouhten, H.; Ronkainen, A.; Hartikainen, A.; Kainulainen, V.; Jalanka, J.; Satokari, R. The Potential of Gut Commensals in Reinforcing Intestinal Barrier Function and Alleviating Inflammation. Nutrients 2018, 10, 988. [CrossRef] [PubMed]

136. Fei, N.; Zhao, L. An opportunistic pathogen isolated from the gut of an obese human causes obesity in germfree mice. ISME J. 2013, 7, 880-884. [CrossRef] [PubMed]

137. Gurung, M.; Li, Z.; You, H.; Rodrigues, R.; Jump, D.B.; Morgun, A.; Shulzhenko, N. Role of gut microbiota in type 2 diabetes pathophysiology. EBioMedicine 2020, 51. [CrossRef] [PubMed]

138. Wang, X.; Ota, N.; Manzanillo, P.; Kates, L.; Zavala-Solorio, J.; Eidenschenk, C.; Zhang, J.; Lesch, J.; Lee, W.P.; Ross, J.; et al. Interleukin-22 alleviates metabolic disorders and restores mucosal immunity in diabetes. Nature 2014, 514, 237-241. [CrossRef] [PubMed]

139. Zhu, C.; Song, K.; Shen, Z.; Quan, Y.; Tan, B.; Luo, W.; Wu, S.; Tang, K.; Yang, Z.; Wang, X. Roseburia intestinalis inhibits interleukin-17 excretion and promotes regulatory T cells differentiation in colitis. Mol. Med. Rep. 2018, 17, 7567-7574. [CrossRef]

140. Gopalakrishnan, V.; Helmink, B.A.; Spencer, C.N.; Reuben, A.; Wargo, J.A. The Influence of the Gut Microbiome on Cancer, Immunity, and Cancer Immunotherapy. Cancer Cell 2018, 33, 570-580. [CrossRef] [PubMed]

141. Klimesova, K.; Kverka, M.; Zakostelska, Z.; Hudcovic, T.; Hrncir, T.; Stepankova, R.; Rossmann, P.; Ridl, J.; Kostovcik, M.; Mrazek, J.; et al. Altered gut microbiota promotes colitis-associated cancer in IL-1 receptor-associated kinase M-deficient mice. Inflamm. Bowel Dis. 2013, 19, 1266-1277. [CrossRef] [PubMed]

142. Wang, X.; Huycke, M.M. Extracellular superoxide production by Enterococcus faecalis promotes chromosomal instability in mammalian cells. Gastroenterology 2007, 132, 551-561. [CrossRef]

143. Singh, N.; Baby, D.; Rajguru, J.P.; Patil, P.B.; Thakkannavar, S.S.; Pujari, V.B. Inflammation and cancer. Ann. Afr. Med. 2019, 18, 121-126. [CrossRef] 
144. Greten, F.R.; Eckmann, L.; Greten, T.F.; Park, J.M.; Li, Z.W.; Egan, L.J.; Kagnoff, M.F.; Karin, M. IKKbeta links inflammation and tumorigenesis in a mouse model of colitis-associated cancer. Cell 2004, 118, 285-296. [CrossRef]

145. Bernstein, C.N.; Blanchard, J.F.; Kliewer, E.; Wajda, A. Cancer risk in patients with inflammatory bowel disease: A population-based study. Cancer 2001, 91, 854-862. [CrossRef]

146. Mira-Pascual, L.; Cabrera-Rubio, R.; Ocon, S.; Costales, P.; Parra, A.; Suarez, A.; Moris, F.; Rodrigo, L.; Mira, A.; Collado, M.C. Microbial mucosal colonic shifts associated with the development of colorectal cancer reveal the presence of different bacterial and archaeal biomarkers. J. Gastroenterol. 2015, 50, 167-179. [CrossRef] [PubMed]

147. Sobhani, I.; Tap, J.; Roudot-Thoraval, F.; Roperch, J.P.; Letulle, S.; Langella, P.; Corthier, G.; Tran Van Nhieu, J.; Furet, J.P. Microbial dysbiosis in colorectal cancer (CRC) patients. PLoS ONE 2011, 6, e16393. [CrossRef] [PubMed]

148. Sun, J.; Kato, I. Gut microbiota, inflammation and colorectal cancer. Genes Dis. 2016, 3, 130-143. [CrossRef]

149. Fukata, M.; Chen, A.; Vamadevan, A.S.; Cohen, J.; Breglio, K.; Krishnareddy, S.; Hsu, D.; Xu, R.; Harpaz, N.; Dannenberg, A.J.; et al. Toll-like receptor-4 promotes the development of colitis-associated colorectal tumors. Gastroenterology 2007, 133, 1869-1881. [CrossRef]

150. Hu, B.; Elinav, E.; Huber, S.; Strowig, T.; Hao, L.; Hafemann, A.; Jin, C.; Wunderlich, C.; Wunderlich, T.; Eisenbarth, S.C.; et al. Microbiota-induced activation of epithelial IL-6 signaling links inflammasome-driven inflammation with transmissible cancer. Proc. Natl. Acad. Sci. USA 2013, 110, 9862-9867. [CrossRef]

151. Ivanov, I.I.; Frutos Rde, L.; Manel, N.; Yoshinaga, K.; Rifkin, D.B.; Sartor, R.B.; Finlay, B.B.; Littman, D.R. Specific microbiota direct the differentiation of IL-17-producing T-helper cells in the mucosa of the small intestine. Cell Host Microbe 2008, 4, 337-349. [CrossRef]

152. Falony, G.; Vieira-Silva, S.; Raes, J. Richness and ecosystem development across faecal snapshots of the gut microbiota. Nat. Microbiol. 2018, 3, 526. [CrossRef]

153. Falony, G.; Joossens, M.; Vieira-Silva, S.; Wang, J.; Darzi, Y.; Faust, K.; Kurilshikov, A.; Bonder, M.J.; Valles-Colomer, M.; Vandeputte, D.; et al. Population-level analysis of gut microbiome variation. Science 2016, 352, 560-564. [CrossRef]

154. Ericsson, A.C.; Gagliardi, J.; Bouhan, D.; Spollen, W.G.; Givan, S.A.; Franklin, C.L. The influence of caging, bedding, and diet on the composition of the microbiota in different regions of the mouse gut. Sci. Rep. 2018, 8, 4065. [CrossRef]

155. Calder, P.C.; Ahluwalia, N.; Albers, R.; Bosco, N.; Bourdet-Sicard, R.; Haller, D.; Holgate, S.T.; Jönsson, L.S.; Latulippe, M.E.; Marcos, A.; et al. A consideration of biomarkers to be used for evaluation of inflammation in human nutritional studies. Br. J. Nutr. 2013, 109 (Suppl. 1), S1-S34. [CrossRef] [PubMed]

156. Furman, D.; Campisi, J.; Verdin, E.; Carrera-Bastos, P.; Targ, S.; Franceschi, C.; Ferrucci, L.; Gilroy, D.W.; Fasano, A.; Miller, G.W.; et al. Chronic inflammation in the etiology of disease across the life span. Nat. Med. 2019, 25, 1822-1832. [CrossRef] [PubMed]

Publisher's Note: MDPI stays neutral with regard to jurisdictional claims in published maps and institutional affiliations.

(C) 2020 by the authors. Licensee MDPI, Basel, Switzerland. This article is an open access article distributed under the terms and conditions of the Creative Commons Attribution (CC BY) license (http://creativecommons.org/licenses/by/4.0/). 